\title{
Former senior editor at The Lancet cries foul over firing for "gross misconduct"
}

Published at www.cmaj.ca on June 23

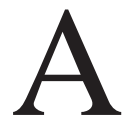
n editorial squabble at The Lancet has resulted in the dismissal of a senior editor, who believes she paid a major penalty for a minor transgression because the journal's publisher, Elsevier, was looking for an excuse to fire her.

On Mar. 20, The Lancet published an editorial appraising the Department for International Development (DFID), the wing of the United Kingdom government that manages foreign aid (The Lancet 2010;375:955). The article stated that "DFID's report card is mixed." But that conclusion, along with several criticisms of the aid agency, did not appear in the praise-filled original version of the editorial submitted by senior editor Dr. Rhona MacDonald.

MacDonald, the lead author of the editorial, says she was not consulted on the changes, which were made by Editor-in-Chief Richard Horton. MacDonald protested, claiming the new version would prove harmful to the world's poor.

"But whatever the ins and outs of the editorial, the editorial writing process was severely breached [which] I think is a very serious violation," MacDonald writes in an email. "We sign all editorials 'The Lancet,' so we have to go through a rigorous democratic process. This did not happen here as Richard rewrote the editorial ... to entirely change its meaning without giving me or anyone else in the leader writing team a chance to make comments."

To disassociate herself from the published version of the editorial, MacDonald contacted sources she had consulted while preparing the article and informed them of what had happened. She also sent them the unpublished version of the editorial that she had submitted. According to MacDonald, Elsevier considered this a breach of the company's policy against sending sen-

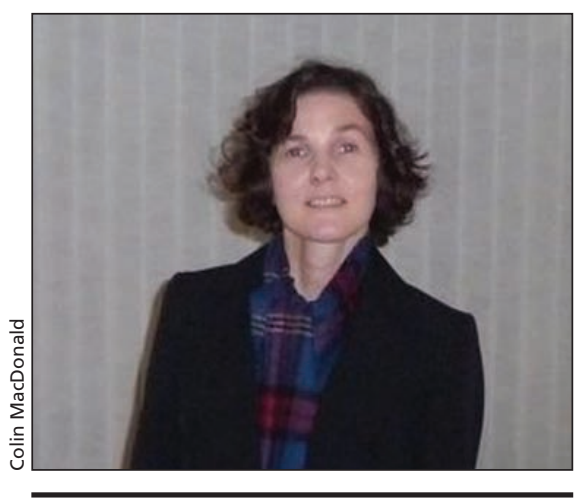

Former Lancet senior editor Dr. Rhona MacDonald suspects that her criticism of journal publisher Elsevier practices, including its close relationship with the pharmaceutical industry and its association with hosting arms fairs, made her unpopular with her employer.

sitive information to third parties and, after two months of disciplinary proceedings, dismissed her for gross misconduct in late May.

But MacDonald, a longtime global health advocate, believes other factors were at play in her firing. During her nearly four years as an editor at The Lancet, she had been outspoken in her criticism of several of Elsevier's practices, including its close relationship with the pharmaceutical industry and its association with hosting arms fairs. This, she suspects, made her unpopular with her employer.

"There is no way that what I did was a sacking matter but Elsevier has wanted rid of me for a while as I campaigned against them over the arms fairs and generally cause them trouble for their questionable behaviour," writes MacDonald.

Elsevier disagrees with MacDonald's version of the incident, but is not providing details of its version. "We have respected the confidentiality of the circumstances of Rhona's departure from the company and wish to continue to do so," Tom Reller, vice president of global corporate relations for Elsevier, writes in an email. "We consider it appropriate to make it clear that the company does not agree with the statements Rhona has made upon her departure, but we do not consider it appropriate to comment further."

According to Stephen Ward, director of the Center for Journalism Ethics at the University of Wisconsin-Madison, being fired does appear to be a disproportionately harsh penalty for sending an unpublished editorial to a third party. "I don't understand why this wasn't resolved in a more amicable way," he says.

But without hearing Elsevier's version of events, he notes, it is difficult to fairly assess the situation. As for changing an editorial to make it more balanced, Horton is the voice of The Lancet, and within his rights, says Ward.

The unpublished version of the editorial, which MacDonald emailed to $C M A J$, reads like a public relations brochure for DFID. It states that the agency's recent work has "further lifted DFID's already elevated stance within the international community" and that "it is difficult to imagine a world without DFID." The editorial even acknowledges its own laudatory nature. "Rarely has a Lancet editorial been so full of praise," it states. "We acknowledge that DFID has its critics but any faults are, in our view, minor niggles rather than major worries."

In the published version, DFID's niggles are not so minor. The department's division between development and foreign policy "weakens the UK's influence internationally," while its "intense and unattractive" competition with the Department of Health has led to poor coordination between the two, and its effort to monitor the effectiveness of programs is lacking. "What the department does well needs to be protected; what it does less well needs to be fixed," the editorial states. 
Though it is not unreasonable for an editor-in-chief to make alterations, it is wrong to publish those changes without first allowing the authors to provide comment, says Ward. He notes, however, that Elsevier disputes that this actually occurred. According to an article in The Guardian, "senior sources at Elsevier insisted that The Lancet had followed its normal editorial rules and that MacDonald had been notified about the proposed changes" (www.guardian .co.uk/media/2010/may/28/lancet-senior -editor-leading-article).
Ward disagrees, however, with MacDonald's claim that she had an ethical duty to explain to her sources why the published version of the editorial would be different. Journalists are not obligated to inform sources about the direction an article will eventually take, he says, and sources who will only speak on condition of a positive story should not be consulted. The primary obligation of a journalist is to provide an accurate account to readers, says Ward.

"She claims to have an ethical obligation to show her original work to sources," says Ward. "I don't see an ethical obligation there at all.

Now that she is no longer employed by The Lancet, MacDonald says she will try to find a job that meets two criteria: helping people, particularly poor and vulnerable populations; and making a significant difference.

"For almost 4 wonderful years, I felt that I could fulfill these criteria at The Lancet," writes MacDonald. - Roger Collier, CMAJ

DOI:10.1503/cmaj.109-3296 